KONSELING: Jurnal Ilmiah Bimbingan dan Konseling

Vol.1, No.2, Januari 2020, pp. 49-54

e-ISSN: 2686-2875

https://journal.ilininstitute.com/konseling

DOI: https://doi.org/10.31960/konseling.v1i2.351

Received on 11/12/2019; Revised on 20/12/2019; Accepted on 13/01/2020; Published on:28/01/2020

\title{
Pengaruh Bermain Game Online Terhadap Disiplin Belajar Siswa
}

\author{
Renaldi Bayu Liminanto \\ Bimbingan Konseling, Universitas Kristen Satya Wacana, Indonesia \\ Corresponding author, E-mail: renaldiebayu1993@gmail.com
}

\begin{abstract}
Abstrak. Tujuan penelitian adalah untuk mengetahui signifikansi pengaruh perilaku bermain game online terhadap disiplin belajar pada siswa kelas X jurusan Ototronik SMK N 3 Salatiga. Variabel dependennya adalah disiplin belajar dan variabel independennya adalah game online. Jumlah subyek penelitian yaitu sebanyak 120 siswa,diambil secara acak sistematis menggunakan interval. Penelitian membutuhkan 55 sampel dari 120 orang, maka jumlah kelompok intervalnya 120/55=2 (kelompok). Selanjutnya responden dibagi ke dalam masing-masing kelompok lalu diambil secara acak tiap kelompok, menggunakan pengumpulan data angket. Teknik analisis data dalam penelitian menggunakan analisis regresi sederhana. Hasil Penelitian menunjukkan bahwa nilai signifikansi regression adalah sebesar 0,000. Mengacu pada kriteria hasil uji hipotesis maka nilai signifikansi $0,000<0,05$, sehingga Ha diterima dan Ho ditolak. Disimpulkan bahwa berarti bahwa Game Online berpengaruh negatif terhadap Disiplin Belajar.
\end{abstract}

Kata Kunci: Game online; Disiplin Belajar; Bermain;

\begin{abstract}
The purpose of this study was to determine the significance of the effect of online game playing behavior on the discipline of learning in class X students majoring in Automatic Engineering SMK N 3 Salatiga. The dependent variable is the discipline of learning and the independent variable is online games. The number of research subjects is 120 students, systematically randomized using intervals. The study requires 55 samples from 120 people, then the number of groups of intervals is $120 / 55=2$ (groups). Furthermore respondents were divided into each group and then randomly taken each group, using questionnaire data collection. Data analysis techniques in the study used simple regression analysis. The results showed that the regression significance value was 0,000 . Referring to the hypothesis test results criteria, the significance value is $0,000<0.05$, so $\mathrm{Ha}$ is accepted and Ho is rejected. It was concluded that meant that Online Games had a negative effect on Learning Discipline.
\end{abstract}

Keywords: Online game; Learning Discipline; Played;

This is an open access article distributed under the Creative Commons Attribution License, which permits unrestricted use, distribution, and reproduction in any medium, provided the original work is properly cited. $(2020$ by author.

\section{Pendahuluan}

Seorang siswa pasti diharapkan memiliki tingkat kedisiplinan yang baik guna meningkatkatkan hasil belajarnya. Alasan mengapa disiplin dan belajar sangat dibutuhkan seorang siswa berikut adalah disiplin menurut Rahman (2011) mengungkapkan bahwa disiplin berasal dari bahasa Inggris discipline yang mengandung beberapa arti. Diantaranya adalah pengendalian diri, membentuk karakter yang bermoral, memperbaiki dengan sanksi, serta kumpulan beberapa tata tertib untuk mengatur tingkah laku. Disiplin sangat penting kaitannya dengan kegiatan belajar mengajar di sekolah. Sikap tersebut dapat menciptakan suasana belajar yang nyaman dan kondusif untuk belajar. Dan belajar adalah suatu proses perubahan yang diperoleh dari usaha yang dilakukan seseorang untuk memperoleh suatu perubahan tingkah laku yang baru secara 
keseluruhan, sebagai hasil pengalamannya sendiri dalam interaksi dengan lingkungannya (Slameto, 2013). Disiplin belajar akan berdampak positif bagi kehidupan siswa, mendorong mereka belajar konkret dalam praktik hidup di sekolah serta beradaptasi (Tu'u, 2004). Dapat disimpulkan disiplin belajar adalah sikap patuh siswa terhadap belajar yang ditunjukkan dengan perbuatan yang mematuhi tata tertib yang berlaku dimana dia berada baik di sekolah maupun di rumah sehingga dia mampu menyesuaikan diri dengan lingkungan dan berkembang guna mencapai prestasi.

Tetapi tidak sedikit hal ini masih dianggap sepele oleh beberapa siswa mereka lebih memilih menghabiskan waktunya di depan layar telepon, kumputer, dan laptop. Sebab di era modern tidak dipungkiri perkembangan teknologi semakin pesat. Salah satu produk teknologi yang sangat nyata saat ini adalah internet. Menggunakan internet tentunya segala sesuatu hal informasi dari seluruh belahan dunia dapat diakses dengan cepat dan mudah. Tidak dipungkiri adanya internet merupakan suatu media yang sangat nyata untuk mendapat informasi terkini. Perkembangan sebuah teknologi yang disalahgunakan sebagaimana mestinya tentunya akan didapati kualitas pendidikan yang menurun karena penggunaan untuk bermain game online. Seiring meningkatnya para pemain game khusunya remaja yang gemar bermain game online hingga menghabiskan waktunya dan tidak berangkat sekolah tentunya memberikan dampak terhadap aktifitas di sekolah. Walaupun masih gejala awal, apabila hal ini tidak ditindak lanjuti tentunya akan berkembang serta menjadi sebuah permasalahan yang sangat sulit untuk diatasi. Pada waktu itulah terjadi ketidakseimbangan dengan orientasi pemanfaatan dari penggunaan internet. Internet memberikan berbagai dampak positif, namun internet pula juga sangat banyak memberikan dampak yang negatif. Menurut Aji (2012) banyak remaja, bahkan anak-anak menghabiskan waktu mereka di depan komputer dan seolah tidak memperhatikan "masa depan" mereka yang sudah di harapkan oleh kedua orang tuanya. Game online sering menjadi permasalahan drop out sekolah, pernikahan dini, hingga tumbuh suburnya sifat introvet atau tertutup dikalangan remaja. Menggunakan internet haruslah bijaksana dalam mengatasi dampak-dampak negatif yang ditimbulkan. Dari dampak negatif menjadi perhatian seluruh lapisan masyarakat dikarenakan melalui internet hendaklah, informasi dan komunikasi yang diperloleh mempunyai sifat yang global. Perkembangan sebuah teknologi yang disalahgunakan sebagaimana mestinya tentunya akan didapati kualitas pendidikan yang menurun karena penggunaan untuk bermain game online. Berdasarkan hasil wawancara yang telah dilakukan dengan guru BK di SMK N 3 Salatiga, banyak siswa yang mengalami permasalahan dalam bidang belajar, meliputi malas dalam belajar, kurang siap dalam mengikuti pelajaran, kurang fokus ketika guru menjelaskan, tidak mengerjakan tugas yang diberikan oleh guru, menurut narasumber (guru BK) para siswa tersebut disaat jam-jam tertentu seperti istirahat mereka lebih sering menghabiskan waktu dengan bermain handphone, Setelah ditinjau lebih lanjut ternyata sebagian besar anak bermain game online, ini pula yang menjadi keresahan para guru, sebab kebiasaan bermain game tersebut mereka lakukan di rumah, dan waktu untuk mengerjakan tugaspun mereka gunakan untuk bermain game online, keterangan tersebut didapatkan oleh guru BK dari guru kelas yang secara langsung bertanya pada siswa yang bersangkutan. Saat penulis melakukan observasi mendapati siswa bermain game online di laptop dan handphone ketika jam kosong dan saat jam istirahat. Berdasarkan latar belakang yang ada maka penulis tertarik untuk meneliti Pengaruh Bermain Game Online Terhadap Disiplin Belajar Siswa Kelas X Jurusan Ototronik SMK N 3 Salatiga.

\section{Metode}

Lokasi penelitian yakni SMK N 3 Salatiga dengan subyek penelitian sebanyak 55 siswa sebagai sampel penelitian. Penelitian ini dimaksudkan untuk mengkaji dua variabel, yaitu: game online sebagai variabel bebas atau yang mempengaruhi (independen), dan disiplin belajar siswa sebagai variabel terikat atau yang dipengaruhi (dependen). Guna memperoleh batasan tentang kedua variabel, maka perlu dibuat definisi operasional dari variabel tersebut, yaitu: 1) Dampak game online, pada dampak ini akan dilihat dari perilaku sosial, kondisi psikis, dan kondisi fisik yang diakibatkan oleh game online yaitu suatu bentuk permainan yang dihubungkan melalui jaringan internet yang melibatkan tiga ranah yaitu fisik motorik, kognisi dan sosio-emosional. Untuk melihatnya dilakukan observasi dan wawancara pada guru dan siswa. 2) Disiplin Belajar adalah 
suatu pengendalian tingkah laku siswa yang menunjukkan ketersedinnya untuk mentaati peraturan atau kaidah-kaidah dalam belajar baik itu belajar yang terjadi di dalam kelas maupun di luar kelas. Faktor yang akan diambil yaitu disiplin belajar di sekolah dan di rumah. Teknik pengumpulan data berupa 2 buah angket yaitu angket dampak game online dan disiplin belajar.

\section{Hasil dan Pembahasan}

Hasil penelitian yang dilakukan terhadap 55 orang siswa mengenai pengaruh bermain game online terhadap tingkat disiplin belajar siswa di SMK N 3 Salatiga. Data diperleh dari angket yang di sebar pada bulan Juli 2019. Adapun hasil penelitian ini diuraikan sebagai berikut:

Analisis Deskriptif Bermain Game Online. Bermain game online pada siswa diukur dengan menggunakan skala yan memiliki empat pilihan jawaban. Skala ini memiliki jumlah pernyataan sebanyak 44 butir dengan skor jawaban tertinggi 4 dan skor jawaban terendah 1 dalam kategori sangat setuju, tidak setuju, setuju, sangat tidak setuju. Berdasarkan hasil analisis statistik didapatkan interval 33 sehingga hasil yang di tabel 1;

Table 1. Distribusi Frekuensi Bermain Game Online

\begin{tabular}{|c|c|c|c|}
\hline Kategori & Interval & Frekuensi & Persentase \\
\hline Sangat Setuju & $143-176$ & 0 & $0 \%$ \\
\hline Setuju & $110-142$ & 22 & $40 \%$ \\
\hline Tidak Setuju & $77-109$ & 25 & $45,45 \%$ \\
\hline Sangat Tidak Setuju & $44-76$ & 8 & $14,54 \%$ \\
\hline \multicolumn{2}{|c|}{ Total } & 55 & $100 \%$ \\
\hline \multicolumn{2}{|c|}{ Min } & \multicolumn{2}{|c|}{44} \\
\hline \multicolumn{2}{|c|}{ Max } & \multicolumn{2}{|c|}{176} \\
\hline
\end{tabular}

Hasil analisi table 1 distribusi frekuensi di atas dapat diketahui bahwa bermain game online pada siswa kelas X Jurusan Ototronik SMK N 3 Salatiga tahun ajaran 2019/2020 sebagian besar berada pada kategori tidak setuju dengan persentase 45,45\%. Disiplin Belajar pada siswa diukur dengan menggunakan skala yang memiliki empat pilihan jawaban. Skala ini memiliki jumlah pernyataan sebanyak 20 butir dengan skor jawaban tertinggi 4 dan skor jawaban terendah 1 . Untuk mengetahui tingkat bermain game online dalam kategori sangat setuju, tidak setuju, setuju, sangat tidak setuju. Berdasarkan hasil perhitungan yang telah dilakukan, didapatkan interval 15 sehingga hasil yang diperoleh sebagai berikut :

Table 2. Distribusi Frekuensi Disiplin Belajar

\begin{tabular}{|c|c|c|c|}
\hline Kategori & Interval & Frekuensi & Persentase \\
\hline Sangat Setuju & $143-176$ & 0 & $0 \%$ \\
\hline Setuju & $110-142$ & 22 & $40 \%$ \\
\hline Tidak Setuju & $77-109$ & 25 & $45,45 \%$ \\
\hline Sangat Tidak Setuju & $44-76$ & 8 & $14,54 \%$ \\
\hline \multicolumn{2}{|c|}{ Total } & 55 & $100 \%$ \\
\hline \multicolumn{2}{|c|}{ Min } & \multicolumn{2}{|c|}{44} \\
\hline \multicolumn{2}{|c|}{ Max } & \multicolumn{2}{|c|}{176} \\
\hline
\end{tabular}

Berdasarkan table 4.3 distribusi frekuensi di atas dapat diketahui bahwa disiplin belajar pada siswa kelas X Jurusan Ototronik SMK N 3 Salatiga tahun ajaran 2019/2020 sebagian besar berada pada kategori setuju dengan persentase $65,45 \%$. 
KONSELING: Jurnal Ilmiah Bimbingan dan Konseling

Vol.1, No.2, Januari 2020

Available online: https://journal.ilininstitute.com/konseling

Renaldi Bayu Liminanto

Hasil Uji Hipotesis

Tabel 3. Hasil Uji Regresi Linier Sederhana

\begin{tabular}{lcccc}
\hline \multicolumn{1}{c}{ Variabel } & B & t hitung & Sig t & Keterangan \\
\hline (Constant) & 76.179 & & & \\
Game Online & -0.251 & -7.306 & 0.000 & Signifikan \\
R Square & 0.502 & & & \\
\hline
\end{tabular}

Pada penelitin ini Teknik Analisis yang digunakan menggunakan Uji Regresi Linier Sederhana yaitu sebuah metode pendekatan untuk pemodelan hubungan antara satu variable dependen dan satu variable independen. Untuk menguji pengaruh dari Game Online terhadap Disiplin Belajar digunakan analisis regresi linier sederhana. Analisis ini merupakan analisa terhadap perubahan variabel terikat oleh variabel bebas. Perhitungan regresi linear sederhana dengan menggunakan program SPSS versi 21.0 jelas pada tabel 3. menunjukkan nilai Konstanta: 79.462. Artinya jika tidak ada variabel Game Online yang mempengaruhi Disiplin Belajar, maka Disiplin Belajar sebesar 79.462 satuan. Kemudian nilai b1 $=-0.299$, Artinya jika variabel Game Online meningkat sebesar satu satuan maka Disiplin Belajar akan meningkat sebesar -0.299 dengan anggapan variable bebas lain tetap.

Tabel 4. Hasil Analisis Regresi

\begin{tabular}{rlrrrrr}
\multicolumn{7}{c}{ SNOVA $^{\mathbf{a}}$} \\
Model & & Sum of Squares & Df & Mean Square & F & \multicolumn{1}{c}{ Sig. } \\
\hline \multirow{2}{*}{1} & Regression & 1679.963 & 1 & 1679.963 & 53.373 & $.000^{\mathrm{b}}$ \\
& Residual & 1668.218 & 53 & 31.476 & & \\
\hline & Total & 3348.182 & 54 & & & \\
\hline
\end{tabular}

a. Dependent Variable: Disiplin

b. Predictors: (Constant), Game Online

Berdasarkan output diatas diketahui nilai signifkansi (Sig.) sebesar $(0.000 \leq 0,05)$ sehingga dapat disimpulkan bahwa H0 ditolak dan Ha diterima, yang berarti bahwa "Ada pengaruh game online $(\mathrm{X})$ terhadap disiplin belajar $(\mathrm{Y})$ ".

Pengujian hipotesis parsial (Uji t). Melalui uji parsial t, bertujuan mengetahui pengaruh secara parsial antara variabel independen yaitu Game Online dengan variabel dependen yaitu Disiplin Belajar. Pengujian signifikansi menunjukkan bahwa terdapat nilai probabilitas sebesar $0.000(0,000 \leq 0,05)$.

Tabel 5. Hasil Analisis Model Summary

\begin{tabular}{llrrr}
\hline Model & R & R Square & Adjusted R Square & \multicolumn{2}{c}{$\begin{array}{c}\text { Std. Error of the } \\
\text { Estimate }\end{array}$} \\
\hline 1 & $.708^{\mathrm{a}}$ & .502 & .492 & 5.610 \\
\hline
\end{tabular}

a. Predictors: (Constant), Game Online

Berdasarkan tabel 5 Hasil analisis model summary, menunjukkan besarnya koefisien determinasi ( $\mathrm{R}$ square) $=0,502$, artinya variabel bebas mempengaruhi variabel terikat sebesar $50,2 \%$ sisanya sebesar $49,8 \%$ dipengaruhi oleh variabel lain yang tidak dimasukkan dalam model penelitian.

\section{Pembahasan}

Hasil penelitian ini menunjukkan bahwa Game Online berpengaruh negatif terhadap Disiplin Belajar. Hal tersebut terbukti dengan nilai t hitung sebesar -7.306 dengan probabilitas 0,000 dimana angka tersebut signifikan karena $(p<0,05)$. 
Seseorang memainkan game online sebenarmya permainan tersebut memberikan manfaat bagi penggunanya. Namun sayangnya, saat ini banyak orang yang telah menjadi pecandu berat permainan tersebut hingga menyalahgunakannya. Khususnya pada anak-anak remaja, game online yang dimainkan secara berlebihan dampaknya justru dapat sangat merugikan. Sebab itu, kedisiplinan seorang yang kecanduan game online sudah tidak berjalan dengan baik dan sangatlah berdampak buruk terhadap dirinya (Santrock, 2009).

Seperti contohnya, dalam segi prestasi, karena selalu sering bermain game, waktu belajar berkurang bahkan bisa sama sekali tidak menyisakan waktu untuk belajar. Dari sisi keuangan, anak pecandu game online cenderung lebih boros, dan menjadikan anak suka berbohong tentang uang, atau bahkan sampai mencuri uang demi bisa bermain game online. Dari segi sosial, tentu pecandu game online mengalami kesusahan dalam hal bersosialisasi, karena kesehariannya lebih asik dengan gadget masing-masing daripada bermain dengan teman sebayanya. Dari sisi kesehatan juga perlu di pertimbangkan, anak yang terlalu banyak bermain game lupa dengan waktu, dan lupa dengan makan, sehingga dapat menganggu jadwal tidur dan jadwal makannya, yang akan menimbulkan penyakit bagi dirinya (Rohman, 2012).

Setiawan (2013) mengungkapkan bahwa dampak bermain game online yaitu kesehatan menurun, gangguan mental, menghambat proses pendewasaan diri, mempengaruhi prestasi belajar anak, pemborosan, serta kesulitan bersosialisasi dengan orang lain. Kecanduan bermain game online merupakan akibat dari tingginya intensitas individu dalam bermain game. Individu yang sudah kecanduan cenderung lebih memilih untuk bermain game daripada mengerjakan pekerjaan yang lain. sehingga kedisiplinan dalam belajar berkurang dan berdampak buruk terhadap prestasi belajar anak disekolah (Prijodarminto, 2009). Hal ini sejalan dengan penelitian yang dilakukan oleh Lusya Ambarwati (2012) dalam penelitian yang berjudul "Pengaruh Perilaku Bermain Game Online Terhadap Disiplin Belajar Terhadap Disiplin Belajar pada Siswa Kelas X SMA Kristen 1 Salatiga Tahun Pelajaran 2013/2014" bahwa ada pengaruh yang signifikan antara perilaku bermain game online terhadap disiplin belajar pada siswa kelas X SMA Kristen 1 salatiga tahun pelajaran 2013/2014 ditunjukan dengan $\mathrm{R}$ Square sebesar 55,2\% dan Sig $=0,000<0,050$. Sumbangan relative perilaku bermain game online sebesar $55,2 \%$ terhadap disiplin belajar.

\section{Simpulan dan Saran}

Berdasarkan hasil penelitian di atas dapat disimpulan bahwa Game Online berpengaruh negatif terhadap Disiplin Belajar. Hal tersebut terbukti dengan nilai t hitung sebesar -7.306 dengan probabilitas 0,000 dimana angka tersebut signifikan karena $(\mathrm{p}<0,05)$. Nilai tersebut dapat membuktikan Ha diterima, yang berarti bahwa "Game Online berpengaruh negatif terhadap Disiplin Belajar"

Berdasarkan kesimpulan di atas maka disarankan: 1) Bagi SMK N 3 Salatiga Memberikan informasi tentang ada atau tidaknya pengaruh perilaku bermain game oline terhadap disiplin belajar siswa, tentunya dengan adanya hal itu dapat dilakukan penindakan yang tegas dan tepat untuk meningkatkan mutu pendidikan. 2) Bagi Guru BK dapat memberi masukan dan lebih meningkatkan pengawasan terhadap penggunaan internet di sekolah, sehingga dampak negatif dalam pemakain internet dapat berkurag, khususnya untuk bermain game online. 3) Bagi Peneliti selanjutnya, hasil penelitian ini dapat dijadikan bukti studi kasus dan acuan atau referensi mengenai pembahasan yang berkaitan dengan topik dalam proses perkuliahan.

\section{Daftar Rujukan}

Aji, C. (2012). Berburu Rupiah Lewat Game Online. PT.Bounabooks.

Ali, Z., Dwikurnaningsih, Y., \& Setyorini. (2019). Pengaruh Dampak Game Online Terhadap Motivasi Belajar Pada Siswa Kelas VIII SMP Kristen 2 Salatiga Tahun Ajaran 2018/2019. Genta Mulia , 122-133.

Ambarwati, L. (2012). Pengaruh Perilaku Bermain Game Online Terhadap Disiplin Belajar pada Siswa Kelas X SMA Kristen 1 Salatiga Tahun Pelajaran 2012/2013. 
Ambarwati, L. (2013). Pengaruh Perilaku Bermain Game Online Terhadap Disiplin Belajar Terhadap Disiplin Belajar pada Siswa Kelas X SMA Kristen 1 Salatiga Tahun Pelajaran 2013/2014. Repository Universitas Kristen Satya Wacana , 1-13.

Anneahira. (2012, October 17). Pengertian Pendidikan. Retrieved from http://anneahira.com/artikel-pendidikan/

Arikunto, S. (2010). Prosedur Penelitian Suatu Pendekatan Praktik. Jakarta: Rineka Cipta.

Asmani, J. (2012). Kiat Mengatasi Kenakalan Remaja di Sekolah. Yogyakarta: P.T Buku Biru.

Aulia, A. (2012). Pembelajaran Kooperatif Tipe TGT untuk Meningkatkan Kedisiplinan dan Prestasi Hasil Belajar Matematika Siswa Kelas X di SMK Sultan Agung Kabupaten Cirebon. Jurnal Online Mahasiswa, 7-10.

Azwar, S. (2012). Penyusunan Skala Psikologi. Yogyakarta: Pustaka Belajar.

Dumrique, D. O., \& Castillo, J. G. (2017). Online Gaming: Impact on the Academic Performance and Social Behavior of the Students in Polytechnic University of the Philippines Laboratory High School. KnE Publishing , 1205-1210.

E.Mulyasa. (2011). Manajemen Pendidikan Karakter. Jakarta: Sinar Grafika Offset.

Kamaratih, D. (2012). Hubungan Antara Kecanduan Bermain Game Online dengan Prokrastinasi Akademik dalam Menyelesaikan Tugas pada Mahasiswa UKSW. Repository Universitas Kristen Satya Wacana , 1-6.

Kamaratih, D. (2012). Hubungan Antara Kecanduan Bermain Online Game dengan Prokrastinasi Akademik dalam Menyelesaikan Tugas pada Mahasiswa UKSW.

Muljahid, M. R. (2016). Kisi-kisi Instrument Penggunaan Game Online. Repository UMY, 104.

Naim, N. 2. (2012). Character Building Optimalisasi Peran Pendidikan dalam Pengembangan Ilmu. Jogjakarta: Ar-Ruzz Media.

Rahman, A. M. (2011). Pentingnya Disiplin Belajar. Jakarta: Rineka Cipta.

Rohman. (2012). Psikologi Karakter Kepribadian. Jakarta: PT Bumi Aksara.

Slameto. (2013). Belajar dan Faktor-faktor Yang Mempengaruhi. Jakarta: Rineka Cipta.

Sugiyono. (2013). Statistika Penelitian. Bandung: Penerbit Alfabeta.

Sugiyono. (2016). Metode Penelitian Kuantitatif, Kualitatif dan R\&D. Bandung: PT Alfabet.

Tarigan, J. M., Soesilo, T. D., \& Irawan, S. (2019). Pengaruh Penggunaan Media Sosial (Instagram) Terhadap Prestasi Akademik Mahasiswa. Jurnal Konseling Andi Martappa .

Thelkar, V. (2018). Impact of Computer Games on Students. International Journal of Engineering Technologies and Management Research , 24-29.

Tu'u, T. (2004). Peran Disiplin pada Perilaku dan Prestasi Siswa. Jakarta: P.T Grasindo. 